\title{
Does Proximity to Wetland Shrubland Increase the Habitat Value for Shrubland Birds of Small Patches of Upland Shrubland in the Northeastern United States?
}

\author{
Bill Buffum ${ }^{1}$ and Richard A. McKinney ${ }^{2}$ \\ ${ }^{1}$ Department of Natural Resources Science, University of Rhode Island, 1 Greenhouse Road, Kingston, RI 02881, USA \\ ${ }^{2}$ National Health and Environmental Effects Research Laboratory, Atlantic Ecology Division, US Environmental Protection Agency, \\ 27 Tarzwell Drive, Narragansett, RI 02992, USA
}

Correspondence should be addressed to Bill Buffum; buffum@uri.edu

Received 13 November 2013; Revised 13 January 2014; Accepted 14 January 2014; Published 20 February 2014

Academic Editor: Kihachiro Kikuzawa

Copyright (C) 2014 B. Buffum and R. A. McKinney. This is an open access article distributed under the Creative Commons Attribution License, which permits unrestricted use, distribution, and reproduction in any medium, provided the original work is properly cited.

\begin{abstract}
The loss of shrubland habitat is linked to population declines for many wildlife species, including several bird species of conservation concern. Conservation agencies in the northeastern United States encourage private landowners to clearcut patches of forest to create shrubland habitat. Many private landowners are only willing to create small clearcuts; therefore, it is important to understand how to maximize the impact of small clearcuts on bird habitat use. In this study we examined whether proximity to wetland shrubland increases the habitat value of small patches of upland shrubland. We conducted point counts at 22 sites containing small patches of upland shrubland ranging in size from 0.1 to 7 ha. Shrubland bird species richness was significantly positively correlated with the proportion of wetland shrubland habitat within $100 \mathrm{~m}$ of a site, and with the extent of all shrubland habitat within $100 \mathrm{~m}$, but not with the proportion of upland shrubland. Occupancy modeling indicated that the size of adjacent wetland shrub patches increased occupancy at the sites for five of eight species observed with sufficient rates of detection. Our results suggest that creating clearcuts adjacent to existing areas of wetland shrubland may enhance the habitat value of the patches for shrubland birds.
\end{abstract}

\section{Introduction}

Conservation of shrubland in the northeastern United States (USA) is important because this habitat is required by many wildlife species but is relatively rare [1]. Most shrubland in the region develops after agricultural abandonment or forest disturbance and succeeds to more mature forest types within a few decades, although it can persist longer in coastal areas exposed to salt spray [2]. The plant species composition of shrubland, also referred to as scrub-shrub, thicket, or brush, depends on many factors and can include both early and late successional species [3].

A dramatic increase in the extent of shrubland in the northeastern USA occurred in the late 19th century after the decline of agriculture as abandoned fields succeeded to shrubland [4]. However, in the late 20th century, the extent of shrubland started a long period of decline as existing areas of shrubland matured into forests and limited amounts of new shrubland were created [4]. An analysis of shrubland habitat in the state of Rhode Island estimated that the 2008 extent of upland shrubland was decreasing by at least $1.5 \%$ annually in noncoastal areas [5]. A number of studies have linked recent declines in wildlife populations in the region to the loss of early successional habitat $[4,6-8]$. For example, the populations of 14 shrubland bird species significantly declined in the three states of Connecticut, Massachusetts, and Rhode Island between 1996 and 2006 while populations of only four species significantly increased [8]. In 2004, the United States Fish and Wildlife Service (USFWS) began formal consideration of the New England cottontail, a native obligate user of shrubland habitat, for threatened or endangered status due to its declining populations [9].

Government and private conservation organizations are actively managing their properties to create shrubland habitat. Encouraging private landowners to create shrubland 
habitat is also a high priority since most forestland in the northeastern USA is privately owned [1]. The Natural Resources Conservation Service (NRCS) of the United States Department of Agriculture encourages private forest owners to create shrubland habitat through programs such as the Wildlife Habitat Incentives Program and the Environmental Quality Incentives Program. However, only 6\% of forest owners in the USA have participated in federal forestry programs to date [10]. Many forest owners have philosophical objections to harvesting their forests and believe that logging is bad for the environment [11]. Forest owners are particularly negative about forest clearcutting, due to concerns about the visual impact of clearcuts and the potential loss of habitat for species which require mature forests [1113]. This poses a challenge for conservation programs, as the most effective method for creating shrubland habitat is generally considered to be clearcutting, which involves removing the entire tree community to encourage the natural regeneration of both shade tolerant and intolerant species $[6,14,15]$.

Most wildlife biologists agree that larger clearcuts create better habitat for shrubland species, but there is not yet consensus on the minimum patch size required for many species. Askins et al. [12] concluded that 0.6 ha patches provide habitat for most shrubland specialists, whereas Schlossberg and King [8] recommended larger openings of at least $1 \mathrm{ha}$. Outreach programs generally follow the pragmatic approach of encouraging landowners to create whatever size clearcut is feasible for their property, and NRCS provides incentives for both large and small clearcuts.

Many landowners are interested in creating habitat for birds but are not able or willing to create clearcuts larger than 1 ha. Therefore, it is important for outreach programs to be able to offer recommendations to landowners about how they can maximize the impact of relatively small clearcuts. Private landowners generally implement clearcuts in upland areas due to restrictions on clearcutting in wetlands. We believe that it may be possible to increase the habitat value of small clearcuts by locating them near existing patches of wetland shrubland, a common land cover type in the region. For example, a recent study in the state of Rhode Island estimated that wetland shrubland comprises $32 \%$ of all shrubland in the state with an average patch size of 1.37 ha [5].

The objective of the current study was to assess whether proximity to wetland shrubland increases the habitat value of small patches of upland shrubland. Many studies have assessed occupancy by songbirds in relation to the patch size of shrubland, but we know of no study that has assessed the impact on occupancy of combining upland and wetland shrubland patches. Specifically we tested the hypothesis that the patch size and extent of combined upland/wetland shrubland are better predictors of occupancy by shrubland birds than the patch size and extent of upland shrubland. We tested this hypothesis separately for three categories of shrubland birds: those that only utilize upland shrubland, those that utilize both upland and wetland shrubland, and all shrubland birds.

\section{Methodology}

2.1. Study Sites. We conducted the study in state of Rhode Island in the northeastern United States (Figure 1). Forests covered $52 \%$ of the state as of 2009 , with dominant tree species being Acer rubrum, Pinus strobus, Quercus velutina, Q. rubra, Q. coccinea, and Q. alba in descending order of total volume (Butler and Payton, 2011). We focused on the state of Rhode Island because it is representative of the region in terms of (a) prevalence of private forest ownership; (b) ongoing decline in the populations of many shrubland wildlife species; and (c) active programs by government and private conservation groups to create shrubland habitat [16-19].

We selected 22 study sites using ArcGIS version10.2. Each study site consisted of a single point located in a shrubland patch. We used spatial datasets which are publicly available on the Rhode Island Geographic Information Systems website (http://www.edc.uri.edu/rigis/). We used "Forest Habitats of Rhode Island" to identify small patches of upland shrubland (mean area: 2.5 ha) adjacent to small patches of wetland shrubland (mean area: $0.8 \mathrm{ha}$ ). Shrubland is defined in the metadata for the dataset as "upland areas dominated by shrubs and small trees with height under 5 meters." We limited potential sites to those located on protected land to simplify the process of obtaining permission to visit the sites, using two GIS data sets: "Conservation Lands Municipal and NGO" and "Conservation Lands: State of Rhode Island." We examined the sites using 2011 imagery and then visited promising sites to confirm that they contained upland or wetland shrubland. Due to the small number of potential sites, we studied all 22 suitable sites without conducting a random selection.

2.2. Bird Counts. We visited each site two times to conduct bird counts in May and June 2011 and conducted one point count per site. During each point count, we waited five minutes and then recorded all birds seen or heard during a ten minute period within $50 \mathrm{~m}$ and $100 \mathrm{~m}$ of the point count center, using a dependent-observer approach [20,21]. The survey teams consisted of a primary observer who noted bird species and abundance, and a secondary observer who recorded data and noted any individuals missed by the primary observer. All point counts were conducted between 0600 and 1000 hours. We categorized bird species as being either shrubland or nonshrubland species (Table 1), based on list of New England shrubland bird species prepared by Schlossberg and King [8]. We further classified the shrubland birds as those that utilize only upland shrubland and those that utilize both upland and wetland shrubland, based on DeGraaf et al. [1, Appendix B.], and noted which shrubland birds were shrubland specialists, based on Askins et al. [12]. We would have included a category of species restricted to wetland shrubland, but no species in this category were detected in the study. We calculated six categories of bird species richness (SR) for each site: SR all species, SR all shrubland species, SR shrubland specialists, SR upland/wetland shrubland species, SR upland shrubland species, and SR nonshrubland species (Table 2). For each species we compiled the number of sites 


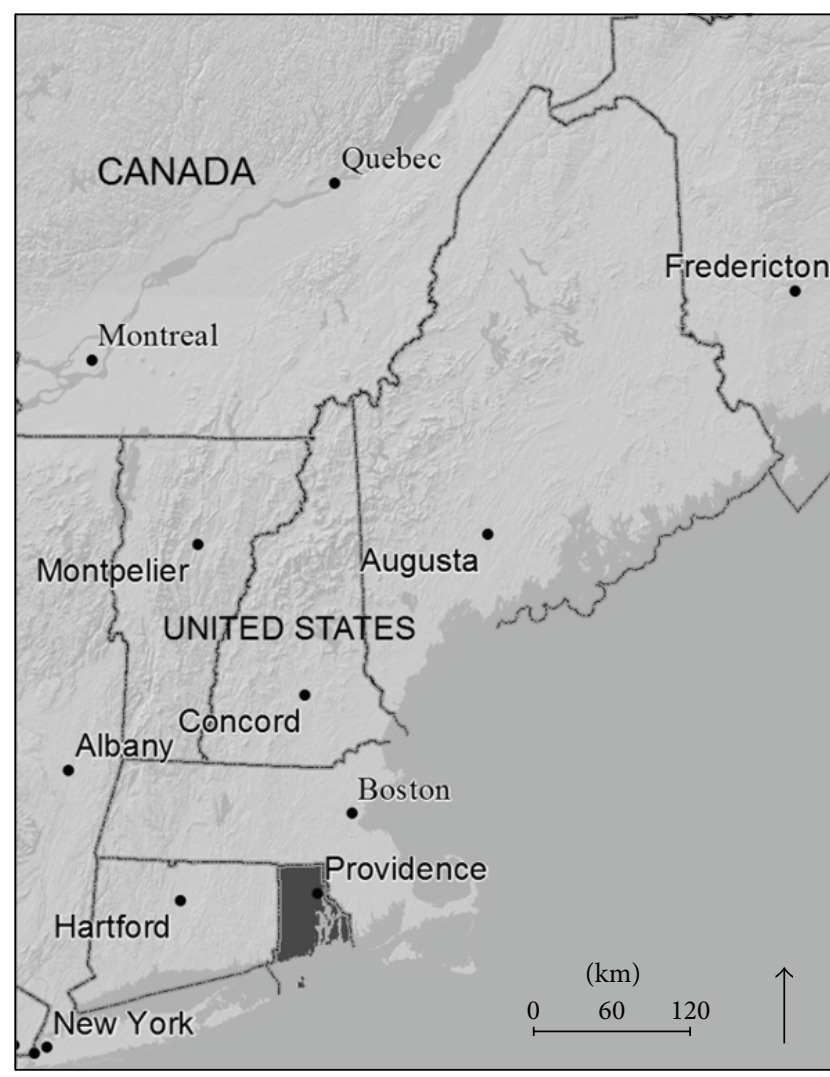

State of Rhode Island

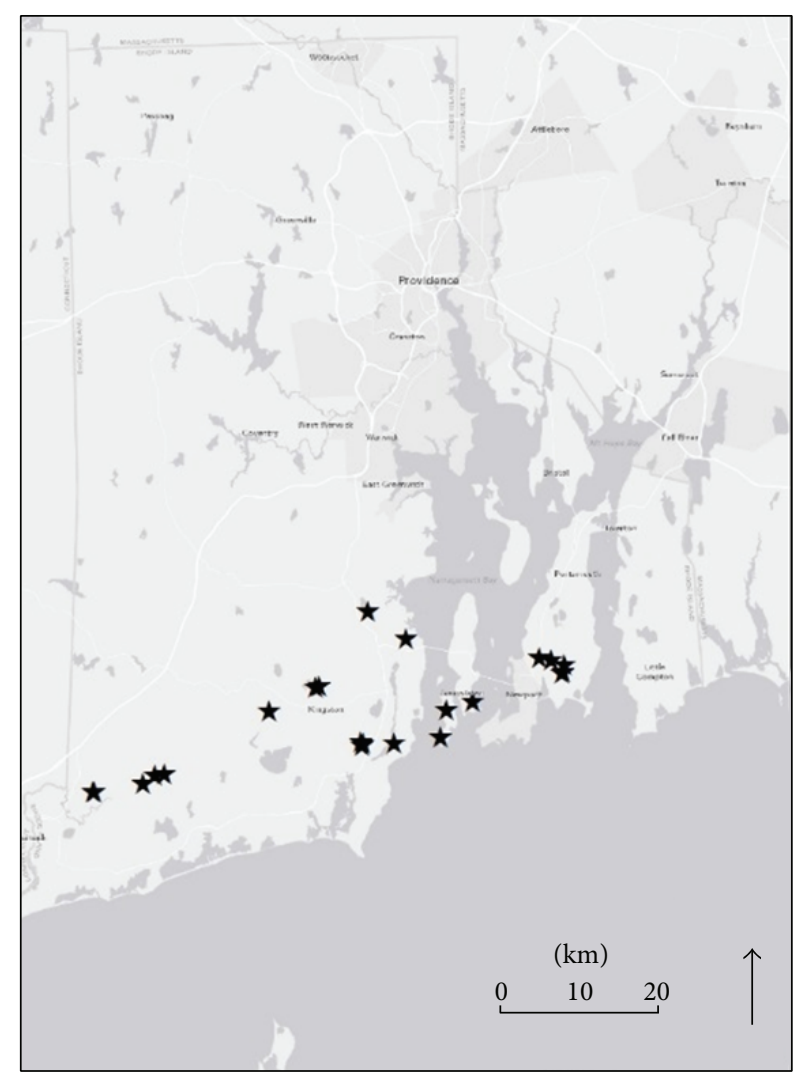

State of Rhode Island

Sites_2011

(a)

(b)

FIGURE 1: Location of study area.

in which the species was detected as well as the total number of observations (Table 1).

2.3. Vegetation Analysis. We conducted vegetation analyses in each site by recording the major species of shrubs and trees at approximately six locations per site (within 100 meters of the center point). At each location we also estimated the percent tree canopy cover using a spherical densitometer and visually estimated the percent shrub canopy cover and shrub height (Table 2). The most common shrub species were Amelanchier stolonifera, Clethra alnifolia, Comptonia peregrine, Ilex verticillata, Kalima angustifolia, Myrica gale, Rosa multiflora, Sambucus Canadensis, Spirea tomentosum, Vaccinium corymbosum, and Viburnum dentatum. We conducted a geographic information system (GIS) analysis of each site using ArcGIS version10.2 and 2011 imagery to assess attributes in 50 meter, 100 meter, and one kilometer buffer areas around the sampling sites. We used the "Forest Habitats of Rhode Island" dataset to quantify the proportion of the buffer areas covered by upland shrubland, wetland shrubland, forest, mowed lawns, and grassland (excluding mowed lawns). We used the Rhode Island Land Use 2003 dataset to quantify percent covered by impervious layer (roads, buildings, etc.) urban areas and human dominated areas.
2.4. Data Analysis. We identified significant correlations between SR of birds with the vegetation and landscape attributes described above. We calculated SR for shrubland birds and nonshrubland birds on the basis of a list of shrubland birds in Southern New England prepared by Schlossberg and King [8], and for shrubland specialists based on a list prepared by Askins et al. [12]. We used IBM SPSS Statistics version 20 to perform bivariate correlations (Kendall's tau for variables without normal distributions) and comparisons of independent samples (Mann Whitney for variables without normal distribution). All results are for two-tailed tests unless otherwise reported: we used one-tailed tests when we expected certain results based on previous studies. For example, several studies have reported that species richness of birds is positively correlated with the patch size of shrubland habitat [22-25]. We focused our statistical analysis on SR rather than abundance: recent studies have highlighted the difficulty in accurately quantifying abundance even with the use of distance sampling [24].

We used the bird species presence/absence data to develop a series of single-species occupancy models to assess landscape and habitat characteristics [26]. We focused on species classified by Schlossberg and King [8] as shrubland species. We selected species that showed sufficient differences in presence between sites to result in robust 


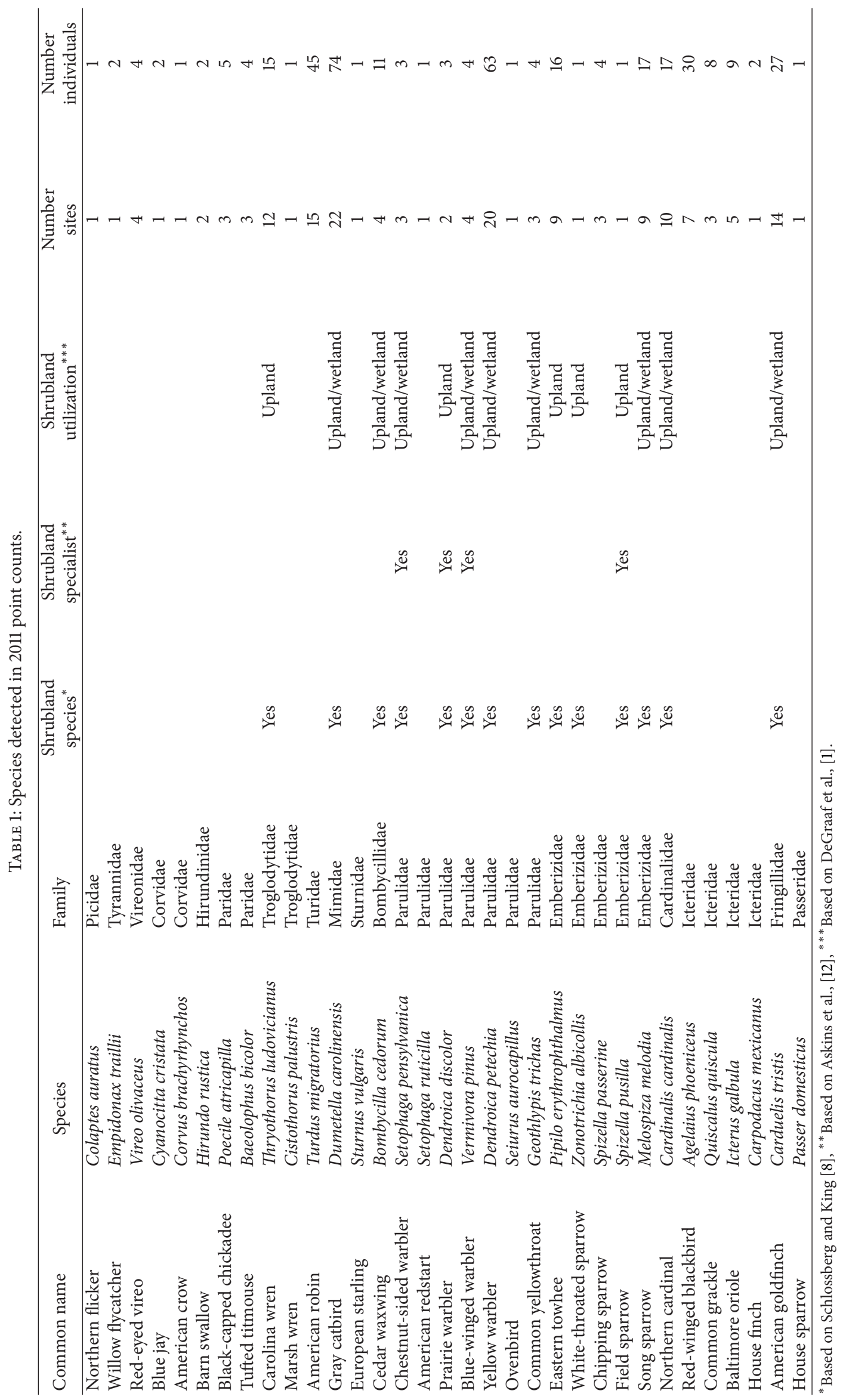


TABLE 2: Attributes of 22 sites studied in 2011.

\begin{tabular}{|c|c|c|}
\hline Attributes & Mean & $\begin{array}{l}\text { Standard } \\
\text { deviation }\end{array}$ \\
\hline \multicolumn{3}{|l|}{ Species richness } \\
\hline All birds & 10.27 & 2.35 \\
\hline \multicolumn{3}{|l|}{ Shrubland birds } \\
\hline Shrubland specialists & 5.95 & 1.21 \\
\hline Wetland/upland shrubland birds & 4.59 & 1.37 \\
\hline Upland shrubland birds & 1.36 & 0.95 \\
\hline Nonshrubland birds & 4.32 & 1.84 \\
\hline \multicolumn{3}{|l|}{ Patch size } \\
\hline Upland shrub (ha) & 2.58 & 4.51 \\
\hline Wetland shrub (ha) & 0.84 & 2.47 \\
\hline All shrub (ha) & 3.42 & 4.75 \\
\hline \multicolumn{3}{|l|}{ Percent of land use within $100 \mathrm{~m}$} \\
\hline Upland shrub (\%) & 0.25 & 0.20 \\
\hline Wetland shrub (\%) & 0.08 & 0.16 \\
\hline All shrubs (\%) & 0.33 & 0.21 \\
\hline Forest (\%) & 0.39 & 0.27 \\
\hline Grassland (\%) & 0.07 & 0.10 \\
\hline Impervious surface (\%) & 0.10 & 0.09 \\
\hline Mowed lawn (\%) & 0.11 & 0.15 \\
\hline All wetland types $(\%)^{*}$ & 0.15 & 0.22 \\
\hline \multicolumn{3}{|l|}{ Percent land use within $50 \mathrm{~m}$} \\
\hline Upland shrub (\%) & 0.45 & 0.26 \\
\hline Wetland shrub (\%) & 0.12 & 0.22 \\
\hline All shrubs (\%) & 0.58 & 0.23 \\
\hline Forest (\%) & 0.34 & 0.24 \\
\hline Grassland (\%) & 0.02 & 0.04 \\
\hline Impervious surface (\%) & 0.03 & 0.05 \\
\hline Mowed lawn (\%) & 0.04 & 0.06 \\
\hline All wetland types $(\%)^{*}$ & 0.17 & 0.27 \\
\hline Shrub height $(\mathrm{m})$ & 3.14 & 1.32 \\
\hline Tree canopy cover $(\%)$ & 0.13 & 0.14 \\
\hline Shrub canopy cover (\%) & 0.40 & 0.28 \\
\hline Urban areas within $1 \mathrm{~km}(\%)$ & 0.28 & 0.20 \\
\hline Human dominated areas within $1 \mathrm{~km}(\%)$ & 0.42 & 0.27 \\
\hline Wetlands within $1 \mathrm{~km}(\%)$ & 0.01 & 0.03 \\
\hline
\end{tabular}

Note: ${ }^{*}$ includes all wetland types listed in the National Wetland Inventory (wetland shrub, wetland forest, open water, etc.).

regression models, which resulted in a candidate list of nine species.

We used an information-theoretic approach to examine the relative importance of the characteristics in explaining overall habitat use. Analysis was carried out using the program Presence [27]. Best habitat characteristic models were determined using small sample Akaike Information Criteria $\left(\mathrm{AIC}_{c}\right)$, which accounts for biases that might arise from relatively small sample size [28]. Models were compared by computing $\mathrm{AIC}_{c}$ differences $\left(\Delta_{i}=\mathrm{AIC}_{c i}-\mathrm{AIC}_{c \text { min }}\right)$
[28]. We considered models with $\Delta_{i}$ between $0-2$ to be wellsupported candidate models, whereas those with $\Delta_{i}>2$ were not well supported. We then used model averaging on candidate models to arrive at a single regression model to explain site occupancy for a species. We also used Akaike weights $\left(w_{i}\right.$; Burnham and Anderson 2002) to compare the relative importance of a variable by summing the $w_{i}$ of all candidate models including the variable and comparing it to the sum of those that do not include the variable.

\section{Results}

We observed 33 bird species during the surveys, including 14 shrubland species (see Table 1 for list of birds with scientific names). As a group, the shrubland species occupied significantly more of our study sites $(M d n=6.5, M=8.14)$ than nonshrubland birds $(M d n=1, M=2.89), U=205.500$, $P<0.01$. Four of the five species observed at more than half of the sites (Carolina wren, American robin, gray catbird, yellow warbler, American goldfinch) were shrubland species. In contrast, only two of the 12 species observed at only one site were shrubland species. We assessed six categories of bird SF and 25 vegetation/land use attributes at each site (Table 2). All of the sites contained at least some upland shrubland, ranging in extent from 0.1 to 7 ha. Thirteen of the sites contained some adjacent wetland, and ten sites contained some wetland shrubland.

There were significant positive correlations between SR of shrubland birds and the patch size of wetland shrub and the patch size of all shrubs, but unexpectedly not with the patch size of upland shrub (Table 3). We also found positive correlations between SR and several attributes related to wetland shrub and all shrubs, but not with the attributes related to upland shrub. We did not find any significant correlations for any of the SR categories with shrub height, tree canopy cover, or shrub canopy cover. In contrast to the shrubland birds, the shrubland specialists did not exhibit any significant correlations between SR and patch size of upland or wetland shrub. SR of shrubland specialists was only significantly correlated with the percent wetland shrub and the percent of all wetlands within $100 \mathrm{~m}$.

We found several differences between the five shrubland species that have been reported to only utilize upland shrubland and the nine species that utilize both upland and wetland shrubland. The SR of upland/wetland shrubland birds was negatively associated with the amount of surrounding forest but positively associated with two attributes related to human dominated landscapes (Table 3). SR of upland shrubland birds, on the other hand, was positively associated with the amount of surrounding forest and negatively associated with three attributes related to human dominated landscapes.

We attempted to generate candidate occupancy models for the nine shrubland species that occupied between $10 \%$ and $90 \%$ of the sites. Models converged for six species, and of these three had positive model coefficients for wetland shrubland within $50 \mathrm{~m}$ of a site (Table 4). Coefficients for four species (Carolina wren, northern cardinal, song sparrow, American goldfinch) were greater for all shrubland, versus just upland shrubland. Two variables had the highest 
TABLE 3: Vegetation and land use attributes that were significantly correlated with species richness of shrubland bird species (attributes not significantly correlated marked as "ns").

\begin{tabular}{|c|c|c|c|c|}
\hline \multirow{2}{*}{ Attributes } & \multicolumn{3}{|c|}{ SR shrubland birds } & \multirow{2}{*}{ All spp. } \\
\hline & Upland/wetland spp. & Upland spp. & Specialist spp. & \\
\hline \multicolumn{5}{|l|}{ Patch size } \\
\hline All shrub (ha) & $\tau=0.37, P<0.05^{*}$ & ns & & $\tau=0.27, P<0.05^{*}$ \\
\hline Wetland shrub (ha) & ns & ns & & $\tau=0.46, P<0.01^{*}$ \\
\hline \multicolumn{5}{|l|}{ Percent land use within $100 \mathrm{~m}$} \\
\hline All shrubs (\%) & $\tau=0.39, P<0.01^{*}$ & ns & & $\tau=0.27, P<0.05^{*}$ \\
\hline Wetland shrub (\%) & ns & ns & & $\tau=0.47, P<0.01$ \\
\hline All wetland types $(\%)^{* *}$ & ns & ns & & $\tau=0.50, P<0.01$ \\
\hline Forest (\%) & $\tau=-0.49, P<0.01$ & $\tau=0.33, P<0.05$ & $\tau=0.38, P<0.05$ & ns \\
\hline Mowed lawn (\%) & ns & $\tau=-0.47, P<0.01$ & $\tau=0.42, P<0.05$ & ns \\
\hline Grassland (\%) & $\tau=0.36, P<0.05$ & & & $\tau=0.39, P<0.05$ \\
\hline \multicolumn{5}{|l|}{ Percent land use within $50 \mathrm{~m}$} \\
\hline All shrubs (\%) & $\tau=0.41, P<0.05$ & ns & & ns \\
\hline Wetland shrub (\%) & ns & ns & & $\tau=0.40, P<0.05$ \\
\hline \multicolumn{5}{|l|}{ Percent land use within $1 \mathrm{~km}$} \\
\hline Urban areas (\%) & $\tau=0.40, P<0.05$ & $\tau=-0.41, P<0.05$ & & ns \\
\hline Human dominated areas (\%) & $\tau=0.50, P<0.01$ & $\tau=-0.36, P<0.05$ & & ns \\
\hline
\end{tabular}

Notes: ns: not significant, ${ }^{*}$ one-tailed test, ${ }^{* *}$ includes all wetland types listed in the National Wetland Inventory (wetland shrub, wetland forest, open water, etc.).

TABLE 4: Coefficients resulting from averaging of the best-supported regression models describing occupancy of nine bird species in relation to vegetation attributes.

\begin{tabular}{lcccc}
\hline Species & Psi & All shrubland & Wetland shrubland & Upland shrubland \\
\hline Carolina wren $^{1}$ & $4.89 \pm 6.82$ & $5.37 \pm 6.22$ & & $-6.12 \pm 8.23$ \\
Cedar waxwing & $-0.19 \pm 1.78$ & $1.69 \pm 2.40$ & $-0.15 \pm 2.04$ & $1.91 \pm 1.86$ \\
Chestnut-sided warbler $^{2}$ & & & & \\
Blue-winged warbler & & & & \\
Eastern towhee & $-0.11 \pm 0.60$ & $-0.70 \pm 0.84$ & & $0.91 \pm 0.95$ \\
Common yellowthroat $^{2}$ & & & $2.39 \pm 2.07$ & 0.95 \\
Northern cardinal $^{\text {Song sparrow }}$ & $-0.27 \pm 0.63$ & $2.83 \pm 1.56$ & $2.51 \pm 1.91$ & $0.18 \pm 2.46$ \\
American goldfinch & $-0.12 \pm 0.70$ & $2.50 \pm 1.34$ & $3.32 \pm 5.31$ & $-0.12 \pm 2.96$ \\
\hline
\end{tabular}

${ }^{1}$ Models containing percent covered by wetland shrub within $50 \mathrm{~m}$ did not converge.

${ }^{2}$ No models converged.

Psi: model intercept; all shrubland: percent covered by all shrubs within $50 \mathrm{~m}$; wetland shrubland: percent covered by wetland shrub within $50 \mathrm{~m}$; upland shrubland: percent covered by upland shrub within $50 \mathrm{~m}$.

relative importance across all occupancy models for four species: wetland shrubland (American goldfinch, Eastern towhee) and all shrubland (northern cardinal, song sparrow) (Table 5). The variable upland shrubland had the highest relative importance for two species (Carolina wren, cedar waxwing).

\section{Discussion}

As expected, our study sites were utilized primarily by shrubland species. For example, four of the five species observed at the most sites were shrubland species, the exception being American robin, an abundant species in Rhode Island and throughout the northeast USA known to use a variety of habitats including forests and shrubland for breeding [29].
Also, the majority of the twelve species observed infrequently at our sites were nonshrubland species. Only two infrequently observed species were classified as a shrubland species: field sparrows and white throated sparrows. While field sparrows are known to utilize the dense shrubland habitat found in our study sites for breeding, they also occupy more open areas such as pastures with limited shrub growth or openings in wood lots [23], so the limited availability of open fields and pastures in our study area may have reduced the use of our study sites by field sparrows. In the northern part of their range, white-throated sparrows breed primarily in boreal coniferous and mixed forest habitats, although in southern New England they may also utilize shrubby forest openings, which were generally not characteristic of our sites [30]. Both species also are known to avoid areas of human habitation 
TABLE 5: Relative importance of variables of the best-supported regression models describing occupancy of nine bird species in relation to vegetation attributes.

\begin{tabular}{lccc}
\hline Species & All shrubland & Wetland shrubland & Upland shrubland \\
\hline Carolina wren $^{\text {Cedar waxwing }}$ & 0.599 & 0.000 & 0.603 \\
Chestnut-sided warbler $^{1}$ & 0.375 & 0.375 & 0.812 \\
Blue-winged warbler $^{1}$ & 0.000 & 0.000 & 0.000 \\
Eastern towhee $^{\text {Common yellowthroat }}{ }^{1}$ & 0.000 & 0.000 & 0.000 \\
Northern cardinal $^{\text {Song sparrow }}$ & 0.343 & 0.403 & 0.290 \\
American goldfinch & 0.000 & 0.000 & 0.000 \\
\hline
\end{tabular}

${ }^{1}$ No models converged.

All shrubland: percent covered by all shrub within $50 \mathrm{~m}$; wetland shrubland: percent covered by wetland shrub within $50 \mathrm{~m}$; upland shrubland: percent covered by upland shrub within $50 \mathrm{~m}$.

such as our study sites, in which $40 \%$ of the area within $1 \mathrm{~km}$ was classified as urban.

Our results supported the hypothesis that the patch size and extent of combined upland/wetland shrubland are better predictors of occupancy for all shrubland birds (i.e., those that utilize upland and/or wetland shrubland habitat) than the patch size and extent of the upland shrubland. We found significant correlations between SR of all shrubland birds and attributes related to both the patch size of all shrubland and the extent of all shrubland habitat (percent all shrub within $100 \mathrm{~m}$ ) but not any attributes related to upland shrubland. We found even stronger significant correlations between SR and attributes related to the patch size of wetland shrubland and the extent of wetland shrubland (percent wetland shrub within $100 \mathrm{~m}$, percent wetland shrub within $50 \mathrm{~m}$ ). Occupancy model results reinforced these findings: for two thirds of the species modeled, inclusion of wetland shrubland extent increased the value of model coefficients, suggesting increased use of sites proximate to wetlands. Also, the relative importance of the extent of either wetland shrubland or all shrubland was the highest for two thirds of the species modeled. The only group of shrubland birds that did not exhibit a significant correlation between SR and patch size of any shrubland attributes was the shrubland specialists. This finding agrees with Askins et al. [12] who found that occupancy of shrubland specialists was not heavily influenced by the area of the habitat patch, as long as the patch accommodates a breeding territory, and suggested that this unusual characteristic of shrubland specialists may reflect adaptations to habitat availability during most of their evolutionary history.

Our findings support the paradigm that larger and more continuous habitat patches increase utilization and occupancy by bird species. Many studies have demonstrated that smaller and more fragmented habitats result in lower occupancy and bird species richness [22-25]. Decreased occupancy may result from constraints on available resources in that smaller patches contain less space for nesting and fewer food resources but may also be influenced by other factors such as increased edge habitat and hence increased potential for exposure to predators and brood parasitism $[31,32]$. Equally important is the landscape setting of habitats: proximity and availability of other nearby natural habitats may also influence occupancy and species richness $[33,34]$.

These results are consistent with previous studies demonstrating enhanced bird use of wetland relative to upland habitats, particularly in areas that are dominated by other habitat types [35]. For example, a study of wetland versus upland utilization by birds in rural and urban landscapes showed higher abundance and species richness of birds in urban wetlands versus urban uplands [36]. A study of utilization in suburban habitats in Minnesota also showed that proximity to wetland habitats and the composition of immediately surrounding land cover may be important in determining bird use of nearby habitats [37]. Overall, our findings suggest that forest management activities which create upland shrubland in proximity to existing patches of wetland shrubland may have a stronger impact on increasing the SR of all shrubland bird species than similar activities in proximity to existing patches of upland shrubland.

Our results also strongly supported the same hypothesis for shrubland birds that utilize both upland and wetland shrubland. We found significant correlations between SR of these species and attributes related to both the patch size of all shrub and the extent of all shrub (percent all shrub within $100 \mathrm{~m}$ ), but not to any attributes related to patch size/extent of either upland or wetland shrubland. Our results did not support the same hypothesis for the species that only utilize upland shrubland: none of the attributes related to patch size was significantly correlated with SR. The lack of significant results for species that only utilize upland shrubland may be due to the small number of species detected in this category (five) as compared to species that utilize both upland and wetland shrubland (nine).

We found several differences between the five shrubland species that have been reported to only utilize upland shrubland and the nine species that utilize both upland and wetland shrubland. The species that utilize both upland and wetland shrubland appeared to be more synanthropic: their SR was significantly positively correlated with the percent of urban 
areas within $1 \mathrm{~km}$ and the percent of human dominated areas within $1 \mathrm{~km}$ but negatively correlated with the percent of forest within $100 \mathrm{~m}$ (Table 3). In contrast, the SR of species that only utilize upland shrubland was negatively correlated with the attributes related to humans and positively correlated with the percent of surrounding forest. When we combined all shrubland birds, we did not find any significant correlations for the attributes related to proximity to humans and forest cover. Other studies have also noted that abundance of species such as the field sparrow declined as the amount of residential/commercial development near survey plots increased [38].

\section{Conclusions}

The current study examined whether proximity to wetland shrubland increases the habitat value of small patches of upland shrubland. Specifically we tested the hypothesis that the patch size and extent of combined upland/wetland shrubland are better predictors of occupancy by shrubland birds than the patch size and extent of upland shrubland. Our results supported the hypothesis for two of three categories of shrubland birds. These findings suggest that landowners who are only able or willing to create small clearcuts can maximize the habitat value of the clearcuts by locating them close to existing areas of wetland shrubland.

\section{Conflict of Interests}

The authors declare that there is no conflict of interests regarding the publication of this paper.

\section{Acknowledgments}

This research was partially supported by a University of Rhode Island (URI) project entitled "Forest Management for Wildlife Habitat in Rhode Island" with funding from URI and the United States Department of Agriculture through a McIntire-Stennis Cooperative Research Grant (RIAESMS975). This is contribution no. 5355 of the University of Rhode Island Agricultural Experiment Station. The authors would like to acknowledge the valuable comments of two anonymous reviewers.

\section{References}

[1] R. M. DeGraaf, M. Yamasaki, W. B. Leak, and A. M. Lester, Technical Guide to Forest Wildlife Habitat Management in New England, Hanover University Press of New England, 2006.

[2] R. E. Latham, "Shrubland longevity and rare plant species in the northeastern United States," Forest Ecology and Management, vol. 185, no. 1-2, pp. 21-39, 2003.

[3] C. G. Lorimer, "Historical and ecological roles of disturbance in eastern North American forests: 9,000 years of change," Wildlife Society Bulletin, vol. 29, no. 2, pp. 425-439, 2001.

[4] D. R. Foster and J. D. Aber, Forests in Time: The Environmental Consequences of 1, 000 Years of Change in New England, New Haven, Yale University Press, 2004.
[5] B. Buffum, S. R. Mcwilliams, and P. V. August, "A spatial analysis of forest management and its contribution to maintaining the extent of shrubland habitat in southern New England, United States," Forest Ecology and Management, vol. 262, no. 9, pp. 17751785, 2011.

[6] R. M. DeGraaf and M. Yamasaki, "Options for managing early-successional forest and shrubland bird habitats in the northeastern United States," Forest Ecology and Management, vol. 185, no. 1-2, pp. 179-191, 2003.

[7] J. A. Litvaitis, "Importance of early successional habitats to mammals in eastern forests," Wildlife Society Bulletin, vol. 29, no. 2, pp. 466-473, 2001.

[8] S. Schlossberg and D. I. King, Ecology and Management of Scrub-Shrub Birds in New England: A Comprehensive Review, Natural Resources Conservation Service, Resource Inventory and Assessment Division, Beltsville, Md, USA, 2007.

[9] J. A. Litvaitis, J. P. Tash, M. K. Litvaitis, M. N. Marchand, A. I. Kovach, and R. Innes, "A range-wide survey to determine the current distribution of New England cottontails," Wildlife Society Bulletin, vol. 34, no. 4, pp. 1190-1197, 2006.

[10] B. J. Butler, "Family Forest Owners of the United States, 2006," Tech. Rep. NRS-27, U.S. Department of Agriculture, Forest Service, Northern Research Station, Newtown Square, Pa, USA, 2008.

[11] M. M. Berlick, D. B. Kittredge, and D. R. Forest, The Illusion of Preservation-A Global Environmental Argument for the Local Production of Natural Resources, vol. 26 of Harvard Forest Paper, Harvard Forest, Harvard University, Petersham, Mass, USA, 2002.

[12] R. A. Askins, B. Zuckerberg, and L. Novak, "Do the size and landscape context of forest openings influence the abundance and breeding success of shrubland songbirds in southern New England?" Forest Ecology and Management, vol. 250, no. 3, pp. 137-147, 2007.

[13] C. A. Costello, M. Yamasaki, P. J. Pekins, W. B. Leak, and C. D. Neefus, "Songbird response to group selection harvests and clearcuts in a New Hampshire northern hardwood forest," Forest Ecology and Management, vol. 127, no. 1-3, pp. 41-54, 2000.

[14] J. A. Litvaitis, "Response of early successional vertebrates to historic changes in land use," Conservation Biology, vol. 7, no. 4, pp. 866-873, 1993.

[15] S. Schlossberg, D. I. King, R. B. Chandler, and B. A. Mazzei, "Regional synthesis of habitat relationships in shrubland birds," Journal of Wildlife Management, vol. 74, no. 7, pp. 1513-1522, 2010.

[16] American Forest Foundation, "Forest conservation in 2009: a farm bill progress report," Tech. Rep., American Forest Foundation, Washington, DC, USA, 2010.

[17] J. D. Oehler, "State efforts to promote early-successional habitats on public and private lands in the northeastern United States," Forest Ecology and Management, vol. 185, no. 1-2, pp. 169-177, 2003.

[18] TNC, "Tillinghast pond management area," The Nature Conservancy, Providence, RI, USA, 2010, http://www.nature.org/ wherewework/northamerica/states/rhodeisland/preserves/art26509.html.

[19] USFWS, "Rhode island national wildlife refuge complex," 200809 Annual Habitat Work Plan, U.S. Fish \& Wildlife Service, Charlestown, RI, USA, 2008, http://www.fws.gov/trustompond/management.html. 
[20] J. D. Nichols, J. E. Hines, J. R. Sauer, F. W. Fallon, J. E. Fallon, and P. J. Heglund, "A double-observer approach for estimating detection probability and abundance from point counts," The Auk, vol. 117, no. 2, pp. 393-408, 2000.

[21] G. M. Forcey, J. T. Anderson, F. K. Ammer, and R. C. Whitmore, "Comparison of two double-observer point-count approaches for estimating breeding bird abundance," Journal of Wildlife Management, vol. 70, no. 6, pp. 1674-1681, 2006.

[22] A. Darabant, P. B. Rai, K. Tenzin, W. Roder, and G. Gratzer, "Cattle grazing facilitates tree regeneration in a conifer forest with palatable bamboo understory," Forest Ecology and Management, vol. 252, no. 1-3, pp. 73-83, 2007.

[23] M. Carey, D. E. Burhans, and D. A. Nelson, Field Sparrow (Spizella Pusilla), The Birds of North America Online, edited by A. Poole, Cornell Lab of Ornithology, Ithaca, NY, USA, 2013, http://bna.birds.cornell.edu/bna/species/103.

[24] F. L. Newell, J. Sheehan, P. B. Wood et al., "Comparison of point counts and territory mapping for detecting effects of forest management on songbirds," Journal of Field Ornithology, vol. 84, no. 3, pp. 270-286, 2013.

[25] R. Sallabanks, J. R. Walters, and J. A. Collazo, "Breeding bird abundance in bottomland hardwood forests: habitat, edge, and patch size effects," The Condor, vol. 102, no. 4, pp. 748-758, 2000.

[26] D. I. Mackenzie, J. D. Nichols, G. B. Lachman, S. Droege, A. Royle, and C. A. Langtimm, "Estimating site occupancy rates when detection probabilities are less than one," Ecology, vol. 83, no. 8, pp. 2248-2255, 2002.

[27] J. E. Hines, Software to Estimate Patch Occupancy and Related Parameters, 2006.

[28] K. P. Burnam and D. R. Anderson, Model Selection and Multimodel Inference: A Practical Information-Theoretic Approach, Springer, New York, NY, USA, 2nd edition, 2002.

[29] P. R. Ehrlich, D. S. Dobkin, and D. Wheye, The Birder's Handbook: A Field Guide To the Natural History of North American Birds, Simon and Schuster, New York, NY, USA, 1988.

[30] J. D. Rising, A Guide to the Identification and Natural History of the Sparrows of the United States and Canada, Academic Press, London, UK, 1996.

[31] L. D. Harris, "Edge effects and conservation of biotic diversity," Conservation Biology, vol. 2, no. 4, pp. 330-332, 1988.

[32] J. P. Hoover, M. C. Brittingham, and L. J. Goodrich, "Effects of forest patch size on nesting success of wood thrushes," The Auk, vol. 112, no. 1, pp. 146-155, 1995.

[33] M. Polyakov, A. D. Rowles, J. Q. Radford et al., "Using habitat extent and composition to predict the occurrence of woodland birds in fragmented landscapes," Landscape Ecology, vol. 28, no. 2, pp. 329-341, 2013.

[34] A. C. Smith, L. Fahrig, and C. M. Francis, "Landscape size affects the relative importance of habitat amount, habitat fragmentation, and matrix quality on forest birds," Ecography, vol. 34, no. 1, pp. 103-113, 2011.

[35] R. A. Mckinney and P. W. C. Paton, "Breeding birds associated with seasonal pools in the northeastern United States," Journal of Field Ornithology, vol. 80, no. 4, pp. 380-386, 2009.

[36] R. A. Mckinney, K. B. Raposa, and R. M. Cournoyer, "Wetlands as habitat in urbanizing landscapes: patterns of bird abundance and occupancy," Landscape and Urban Planning, vol. 100, no. 12, pp. 144-152, 2011.

[37] K. L. Petersen and A. S. Westmark, "Bird use of wetlands in a midwestern metropolitan area in relation to adjacent land cover," The American Midland Naturalist, vol. 169, no. 1, pp. 221228, 2013.
[38] R. A. Askins, C. M. Folsom-O’Keefe, and M. C. Hardy, "Effects of vegetation, corridor width and regional land use on early successional birds on powerline corridors," PLoS ONE, vol. 7, no. 2, Article ID e31520, 2012. 

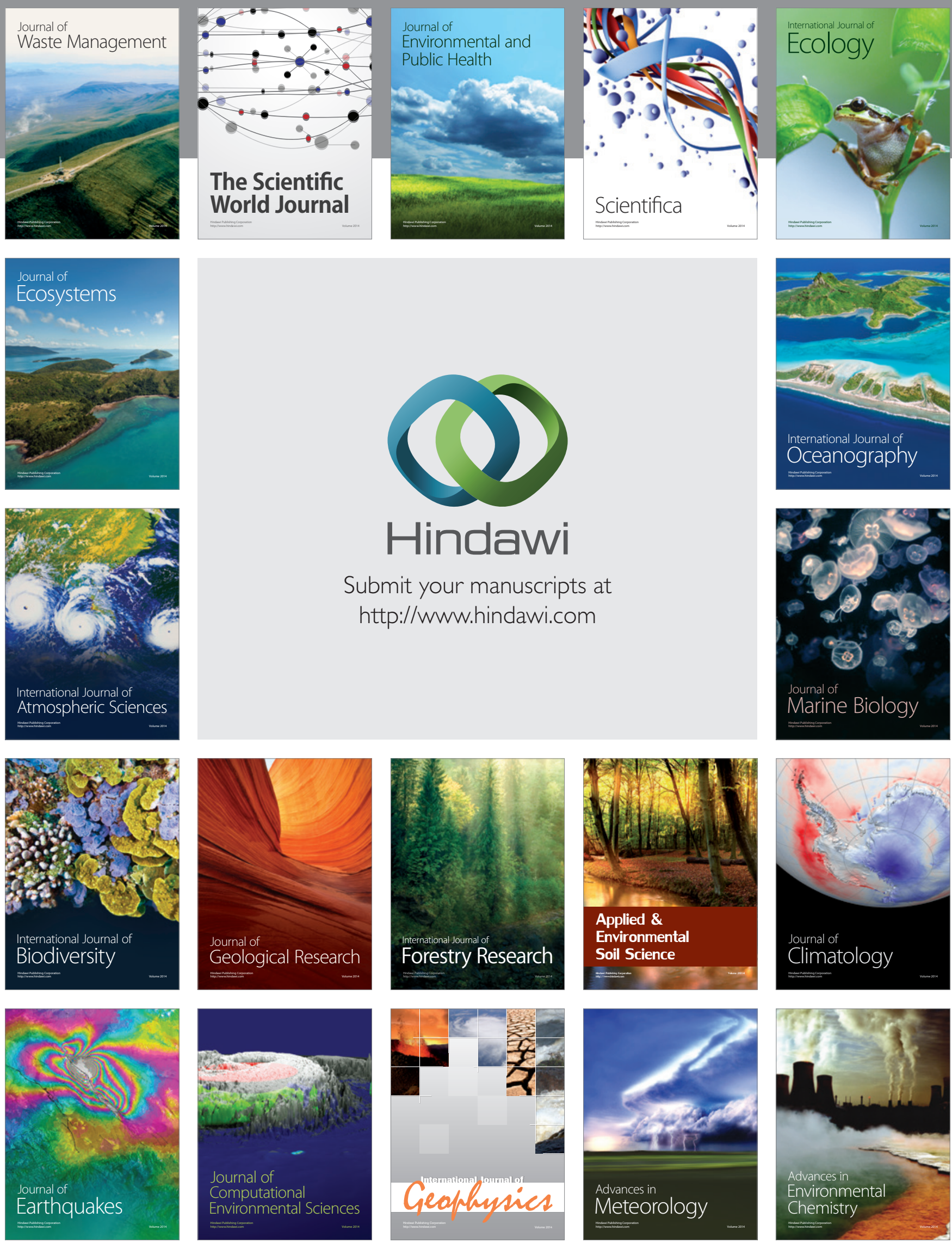